\title{
Evolution of the Lesser Himalaya
}

\author{
ON Bhargava ${ }^{*}$ and W Frank ${ }^{2}$
}

\author{
1 103, Sector 7, Panchkula 134109, India, 253/8 Ferrogasse Vienna 1040, AUSTRIA \\ *For correspondence, e-mail: onbhargava@yahoo.co.in
}

The earliest rocks found in the Lesser Himalaya are gneisses and crystallines in which the $1860 \mathrm{Ma}$ Jeori-Wangtu-Bandal Granite-gneiss Complex (JWBC) is intrusive. It forms the basement complex for the oldest Lesser Himalayan rocks and are a possible extension of the Peninsular rocks. In stratigraphic/ parautochthonous position it is found only in the Himachal and J\&K (Kishtwar). In the Eastern Himalaya, the basement rocks occur as tectonic slivers. Once the JWBC was cratonised there was a formation of paleosol prior to the $1800 \mathrm{Ma}$ rifting. The JWBC is also involved in thrusting and forms a tectonic marker (Baragaon/Gahr) throughout the Himalaya.

The history of the Himalaya commenced with a rifting manifested by 1800 Ma Rampur and equivalent volcanics. This event created a shallow marine basin in which the Rampur Group and equivalent sequences (Sundernagar, Dharagad, Berinag, Kuncha, Daling, Shumar groups) along with tholeiites were laid. Duration of the Rampur Group sedimentation is uncertain, but the basin certainly terminated prior to $1500 \mathrm{Ma}$ i.e. the age of the basal part of the overlying Shali Group and its equivalents. The Kulu Thrust sheet involving the JWB basement was possibly nucleated between $1800 \mathrm{Ma}$ and $1500 \mathrm{Ma}$.

After a hiatus, the sedimentation of the carbonate sequences of the Shali and equivalent successions (Larji, Deoban, Calc "Series", Nawakot, Baxa) took place. The stromatolites in these $3000 \mathrm{~m}$ thick carbonate sequences, indicate an age range between 1500-1000 Ma. It looks improbable that only 3000 $\mathrm{m}$ thick sequences should have been deposited during $500 \mathrm{Ma}$ time-span, which almost equals the entire Phanerozoic. Several sedimentological breaks in between the carbonate sequences are probable and many of the shale horizons in these carbonate sequences may represent paleosols.

The carbonate sedimentation ceased with another rifting around $1000 \mathrm{Ma}$. The rifting caused outpouring of the Tattapani and Peontra tholeiitic volcanics. The rise of thermal dome formed the Chaur Granite. The Jutogh Thrust Sheet was possibly nucleated at this juncture. The raised Rampur and Deoban and equivalent terrains provided clasts to the Basantpur and Mandhali diamictites culminating in the deposition of the Simla-Jaunsar groups in the same basin. The detrital mica in the Sanjauli Formation (Simla Group) and Nagthat Formation (Jaunsar Group) are 860 Ma old, thus indicating these formations to be younger to this age. The mica and illite have chemical signatures of the Erinpura Granite. This basin was possibly confined mainly between Nepal and Jammu, as its equivalents are not known in the Eastern Himalaya. The sedimentation possibly terminated around $750 \mathrm{Ma}$ to allow time to raise the Simla and Jaunsar groups and their consequent extensive erosion before the sedimentation of 700-650 Ma Blaini sequence. This regression was accompanied by rising of upland between the Himalaya basin and the Aravalli terrain.
The clasts in the glaciomarine Blaini diamictites are from the Himalayan source, suggesting the glaciers to have emanated from the raised Simla-Jaunsar upland, which had cut off supply from the peninsular part. There were two glaciations intervened by an interglacial period. After the deposition of the cap carbonate, there was a regression and the basin was confined to a smaller part in which Infra-Krol and Krol sequences were deposited. At the termination of the Krol sedimentation, close to the PrecambrianCambrian boundary, the Outer Krol Belt part was raised and the Tal sedimentation continued in the Krol Basin sited over the Jaunsar Group. This basin too was confined mainly between Nepal and Himachal. Upwelling currents from an open sea, as indicated by presence of cerium, concentrated the phosphorite in the Tal Group. The open sea was separated from the Tal Basin by a submarine ridge. Another basin towards SE of the Krol basin was created, in which the Chilar Formation was deposited. The Chilar quartzitearenites enclose $1860 \mathrm{Ma}$ detrital mica, whereas the Tal quartzitearenite have $860 \mathrm{Ma}$ detrital mica. Presence of age specific micas in the Chilar and Tal sediments indicates that a barrier separated the basins of these two formations to preclude intermixing of micas of two different ages. The Outer Krol Belt, which lacks the Tal sediments, formed this barrier. The Tal basin relatively subsided, which resulted in greater depth of burial, leading to higher grade of anchimetamorphism in the Jaunsar Group as compared to the Simla Group. The Tal quartzarenites are younger than $525 \mathrm{Ma}$--the age of enclosed detrital zircons. Zircons of the same age are found in the Middle Cambrian Kunzam La Formation of the Tethyan Himalaya also, thereby indicating a common provenance. The submarine ridge referred to above, mainly made up of Vaikrita Group with Early Palaeozoic granites, became aerial and contributed sediments to the Tal basin as well as the Kunzam La basin on the Tethyan side during the Middle Cambrian.

The Tal basin terminated around $520 \mathrm{Ma}$ due to late Cambrian thrusting event, which was experienced over the entire length of the Himalaya. Suturing in the northern part of the then Indian Plate caused this tectonic event. The folds generated during this event are co-axial with the Himalayan folds. The suturing and resultant thrusting caused a regional hiatus covering the Late Cambrian and generation of Early Paleozoic granites all over the Himalaya in the Vaikrita Crystalline. The Vaikrita Thrust Sheet too was nucleated at this time and on its back carried the Kunzam La basin, which contributed clasts to the Thango Formation of the Tethyan basin.

After this event the Lesser Himalayan terrain became a positive area, with drainage heading towards the Tethyan part. At the beginning of the Permian, associated with rifting in the Gondwanaland, old lineaments, mainly in the present foothill parts opened and provided pathway to Permian sea right from 
Arunachal to Uttarkhand. The sea lasted only during the Early Permian, its withdrawal coinciding with Midian regression and sedimentological break in the Tethyan part. Thereafter Lesser Himalaya again became a positive area.

The rifting/drifting during Cretaceous again re-opened old lineaments for the transgression of Late Cretaceous Sea between Uttarkhand and Arunachal. The sea withdrew around $70 \mathrm{Ma}$. Thereafter erosion in subtropical climate led to the formation of bauxite. The subduction of the Indian plate had already commenced, the Lesser Himalayan part arched and the foreland basin formed at the present foothill region; its embayments extended quite far over the Mesoproterozoic carbonate belts and Neoproterozoic Simla-Krol, Cambrian Tal, Permian Bijni and Cretaceous Nilkanth parts. The Subathu sediments derived material from the northern and partly from southern (peninsula) sources and from the Wazirstan-Khost area. The sedimentation in a marine basin continued up to $44 \mathrm{Ma}$, thereafter (Passage Beds) the paralic conditions set in that lasted till $40 \mathrm{Ma}$. In shallower part of the basin there was a break in sedimentation during the Late Eocene. The thrust sheets, which were nucleated in the Precambrian times were reactivated and were partly bared. The
Dagshai and equivalent basins were mainly deposited in estuaries and extensive flats. The Dagshai and the Passage Beds had their provenance in sedimentary sequences and also from the rising crystalline thrust sheets. The overlying Kasauli Formation represents brackish water environment with distinct supply mainly from the low grade crystalline. As the thrust sheets further emerged as a consequence of continued subduction of the Indian Plate, these advanced towards the south and the foreland basin shifted towards farther south in which typical molassic sediments of the Siwalik were deposited.

Due to impact of advancing crystalline thrust sheets the Shali and Simla groups' rocks moved partly over the Paleogene of the foreland basin and Krol Belts slid on their floors as superficial thrust sheets. The Late Cambrian folds, which are co-axial with the Himalayan folds, got accentuated and also selectively overturned, whereas the Himalayan folds (e.g. Jutogh, Krol, Tons and Kulu thrusts) remained largely open and upright. The Himalaya acquired the present elevation and various weathering processes became active, with the removal of overburden due to extensive erosion the stresses were released and various faults were reactivated from time to time. 